\title{
DRINKING WATER AND CANCER MORTALITY*
}

\author{
ROBERT M. CLARK and JAMES A. GOODRICH
}

Drinking Water Research Division, Water Engineering Research Laboratory, U.S. Environmental Protection Agency, Cincinnati, Ohio 45268 (U.S.A.)

\section{ROLF A. DEININGER}

Department of Environmental and Industrial Health, The University of Michigan, School of Public Health, Ann Arbor, Michigan 48109 (U.S.A.)

(Received October 8th, 1985; accepted December 5th, 1985)

\section{ABSTRACT}

The problem of understanding the possible adverse health effects of organic chemical contaminants in drinking water is not new, but national concern has intensified in recent years. Despite this concern and regulatory efforts, no definitive relationship has been established between organic contamination and human health effects.

This paper examines some of the sources of possible organic contamination, current knowledge concerning human health effects and the most current epidemiological data. Historic CCE and CAE data were extracted from STORET and used in regression analyses. Age-adjusted 20-year average cancer mortality rates were regressed against the sum of CAE and CCE for those counties with STORET monitoring data of their drinking water source. Results indicate statistically highly significant relationships particularly for GI-urinary tract cancers.

\section{INTRODUCTION}

Concern over possible adverse health effects of organic chemical contaminants in drinking water is not new. In 1956, while developing the carbon filter technique of sampling for organics in drinking water, Middleton and Rosen reported on the level of organic materials in the Ohio River, a source of drinking water for many communities [1]. In 1962, a recommended limit was set at $200 \mu \mathrm{g}$ per liter of carbon chloroform extract (CCE) to

\footnotetext{
* Although the research described in this article has been funded partly by the United States Environmental Protection Agency under assistance agreement CR 808857-01-0 to the University of Michigan, it has not been subjected to the Agency's peer and administrative review and therefore may not necessarily reflect the views of the Agency and no official endorsement should be inferred.
} 
TABLE 1

SOURCES OF CARCINOGENIC CHEMICALS FOUND IN WATER

\begin{tabular}{|c|c|c|}
\hline Class of compound & Source & $\begin{array}{l}\text { Method of } \\
\text { introduction }\end{array}$ \\
\hline \multicolumn{3}{|l|}{ Petrochemicals } \\
\hline $\begin{array}{l}\text { Oil(s) } \\
\text { Polycyclic aromatics } \\
\text { Methylated naphthalenes }\end{array}$ & \multirow{2}{*}{$\begin{array}{l}\text { Refinery waste, } \\
\text { petrochemical plants, } \\
\text { service stations, metal } \\
\text { working plants, ships, } \\
\text { carriers for pesticides, } \\
\text { asphalted roads }\end{array}$} & $\begin{array}{l}\text { Water discharge, } \\
\text { spills }\end{array}$ \\
\hline $\begin{array}{l}\text { Kerosene } \\
\text { etc. }\end{array}$ & & $\begin{array}{l}\text { Rain, runoff, } \\
\text { direct application, } \\
\text { spills }\end{array}$ \\
\hline \multicolumn{3}{|l|}{ Coal tar } \\
\hline & \multirow{4}{*}{$\begin{array}{l}\text { Coke ovens, tar } \\
\text { distilleries, tar } \\
\text { paper plants, wood } \\
\text { treating, gas plants }\end{array}$} & \multirow[t]{4}{*}{$\begin{array}{l}\text { Waste discharge, } \\
\text { spills }\end{array}$} \\
\hline Creosote & & \\
\hline Anthracene & & \\
\hline $\begin{array}{l}\text { Aromatic hydrocarbons } \\
\text { etc. }\end{array}$ & & \\
\hline \multicolumn{3}{|l|}{$\begin{array}{l}\text { Aromatic-amino and -nitro } \\
\text { compounds }\end{array}$} \\
\hline $\begin{array}{l}\text { Benzidine } \\
\text { 4-Aminodiphenyl } \\
\text { Beta-naphthylamine } \\
\text { etc. }\end{array}$ & $\begin{array}{l}\text { Dye and rubber plants, } \\
\text { pharmaceutical plants, } \\
\text { textile dying operations, } \\
\text { plastics plants }\end{array}$ & $\begin{array}{l}\text { Waste discharge, } \\
\text { spills }\end{array}$ \\
\hline \multicolumn{3}{|l|}{ Pesticides } \\
\hline DDT & Manufacturing operations, & Waste discharge \\
\hline $\begin{array}{l}\text { Dieldrin } \\
\text { Aramite }\end{array}$ & use of pesticides & $\begin{array}{l}\text { spills, } \\
\text { rainfall. }\end{array}$ \\
\hline Carbon tetrachloride & & runoff, \\
\hline $\begin{array}{l}\text { Acetamide } \\
\text { etc. }\end{array}$ & & settling from air \\
\hline
\end{tabular}

prevent the "unwarranted dosage of the water consumer with ill-defined chemicals" [2].

In 1974 two papers were published that heightened interest in the subject of drinking water in the U.S. and The Netherlands. These papers reported that the use of chlorine as a disinfectant increases the concentration of certain halogenated organics in drinking water. Of the organic compounds created during chlorination, trichloromethane, commonly called chloroform, is formed in the greatest quantities $[3,4]$.

A national survey, of 80 water supplies, found the universal problem of chloroform contamination following chlorination. As part of that study an attempt was made to characterize as completely as possible the purgeable organic chemicals in five typical water supplies. A total of 72 compounds were identified in the drinking water of the five cities [5, 6]. Concurrent with this work the National Cancer Institute (NCI) completed a study on 
chloroform as a carcinogen. Results indicated that chloroform was a carcinogen in test animals [7].

In 1976 Page, Harris and Epstein purported to establish the relationship between drinking water and cancer mortality in Louisiana [8]. Eventually, 86 specific organic chemicals were identified in New Orleans drinking water [9].

As a reflection of this concern over the effects of organic contamination in drinking water, EPA issued an Advanced Notice of Proposed Rule-making for organic chemical contaminants in drinking water. The rule proposed regulations to deal with the control of chloroform and synthetic organics in drinking water. Eventually the regulation regarding synthetic organics was dropped and a regulation limiting the amount of trihalomethane in drinking water was promulgated [10].

Despite these efforts and concerns over the problems of organics in drinking water no definitive relationship has been established between organic contamination and human health effects. In this paper, some of the available knowledge concerning cancer mortality and the contamination of drinking water by organics will be examined. An attempt will be made to introduce a new treatment of some existing data to provide additional insight into the possibility of such a relationship. As background for this analysis in the following sections, some of the sources of possible organic contamination will be discussed; current knowledge concerning human effects will be examined, and the most current epidemiological data will be presented.

\section{SOURCES OF DRINKING WATER CONTAMINATION}

Organic contamination primarily affects surface water supplies, which have become the repository for the waste discharges of numerous industrial facilities and municipalities as well as urban and agricultural runoff. These surface supplies are also frequently sources of drinking water.

At the time of the passage of the Safe Drinking Water Act of 1974, there were more than 12000 chemical compounds known to be in commercial use with many more being added each year. The causes of synthetic organic chemical contamination are chronic and variable in nature. Table 1 lists some major contributors and their possible source and method of introduction into drinking water [11].

Industrial discharges from point sources are regulated by the Federal Water Pollution Control Act Amendment's National Permit Discharge Elimination System. Despite this "control" of industrial discharges through the nation-wide permit system, some toxic pollutants continue to be discharged into surface waters. In addition, there is always the possibility of accidental or deliberate spills. Additionally, there are any number of nonpoint sources which may contribute highly toxic pesticides and stormwater runoff carrying other potentially harmful substances. 
TABLE 2

SELECTED CARCINOGENS AND MUTAGENS IN 11-CITY SURVEY

\begin{tabular}{|c|c|c|c|c|c|c|c|c|c|c|c|}
\hline Compound & N.O & Mia & Sea & Ott & Phi & $\mathrm{Cin}$ & Tuc & NYC & Law & Gr.F & Tr.P \\
\hline Benzene & $\mathrm{x}$ & & & $\mathrm{X}$ & $\mathbf{x}$ & $\mathrm{x}$ & & & & & \\
\hline Carbon tetrachloride & $\mathrm{x}$ & $\mathrm{x}$ & & $\mathbf{X}$ & $\mathrm{X}$ & $\mathrm{x}$ & & $\mathrm{X}$ & $\mathrm{X}$ & $\mathrm{x}$ & $\mathbf{x}$ \\
\hline Bis(2-chloroethyl)ether & $\mathrm{X}$ & & & & & $\mathrm{x}$ & & $\mathrm{X}$ & $\mathrm{X}$ & $\mathrm{x}$ & $\mathrm{X}$ \\
\hline Chloroform & $\mathrm{x}$ & $\mathrm{X}$ & $\mathbf{X}$ & $\mathrm{X}$ & $\mathbf{X}$ & $\mathrm{X}$ & $\mathbf{X}$ & $\mathrm{X}$ & $\mathbf{X}$ & $\mathrm{X}$ & $\mathrm{X}$ \\
\hline 1,2-Dichloroethane & $\mathrm{X}$ & $\mathbf{X}$ & & & $\mathbf{X}$ & $\mathbf{X}$ & & & & & \\
\hline Dieldrin & $\mathrm{X}$ & $\mathrm{X}$ & $\mathbf{X}$ & $\mathrm{X}$ & & $\mathrm{X}$ & & & & & \\
\hline DDT,DDE & $\mathrm{X}$ & & & & & & & & & & \\
\hline Hepachlor & $\mathrm{X}$ & & & & & & & & & & \\
\hline Hexachlorobenzene & $\mathrm{X}$ & & & & & & & & & & \\
\hline Lindane $(\gamma$-BHC) & & & & & & $\mathrm{X}$ & & & & & \\
\hline PCB & & & & & & $\mathbf{X}$ & & & & $\mathrm{X}$ & \\
\hline Tetrachloroethylene & $\mathbf{x}$ & $\mathbf{x}$ & & $\mathbf{x}$ & $\mathrm{x}$ & $\mathrm{x}$ & $\mathrm{X}$ & $\mathrm{X}$ & $\mathbf{x}$ & $\mathrm{x}$ & \\
\hline Trichloroethylene & $\mathbf{x}$ & $\mathbf{X}$ & & $\mathrm{X}$ & $\mathbf{X}$ & $\mathbf{x}$ & & & $\mathbf{X}$ & & \\
\hline Vinyl chloride & & $\mathbf{X}$ & & & $\mathrm{x}$ & & & & & & \\
\hline Bromodichloromethane & $\mathrm{X}$ & $\mathrm{X}$ & $\mathrm{X}$ & $\mathrm{x}$ & $\mathbf{X}$ & $\mathrm{X}$ & & $\mathrm{X}$ & $\mathrm{X}$ & $\mathrm{X}$ & $\mathrm{X}$ \\
\hline Chlorobenzene & $\mathrm{X}$ & $\mathrm{X}$ & $\mathrm{X}$ & $\mathrm{X}$ & $\mathrm{X}$ & $\mathrm{X}$ & & $\mathbf{x}$ & $\mathbf{X}$ & $\mathbf{X}$ & $\mathrm{X}$ \\
\hline Chloromethylether & $\mathrm{x}$ & & & & & & & & & & \\
\hline Dibromochloromethane & $\mathrm{X}$ & $\mathrm{X}$ & $\mathrm{X}$ & & $\mathrm{X}$ & $\mathbf{X}$ & $\mathrm{X}$ & $\mathrm{X}$ & $\mathbf{X}$ & $\mathbf{x}$ & $\mathrm{X}$ \\
\hline 1,3-Dichlorobenzene & $\mathrm{X}$ & $\mathrm{X}$ & & & $\mathbf{x}$ & $\mathbf{x}$ & & & $\mathbf{x}$ & & \\
\hline Dichloromethane & $\mathrm{X}$ & $\mathrm{X}$ & & & $\mathrm{X}$ & $\mathbf{X}$ & & $\mathbf{X}$ & $\mathbf{x}$ & $\mathbf{X}$ & $\mathrm{X}$ \\
\hline Methylene chloride & $\mathbf{X}$ & $\mathrm{X}$ & $\mathrm{X}$ & $\mathrm{X}$ & $\mathbf{x}$ & $\mathrm{X}$ & & $\mathrm{X}$ & $x$ & $\mathbf{X}$ & $X$ \\
\hline Vinylidene chloride & $\mathbf{X}$ & $\mathrm{x}$ & & & $\mathrm{X}$ & $\mathrm{X}$ & & & $\dot{x}$ & & \\
\hline
\end{tabular}

N.O $=$ New Orleans $;$ Mia $=$ Miami $;$ Sea $=$ Seattle $;$ Ott $=$ Ottumwa, Iowa $; \mathrm{Phi}=$ Philadelphia $;$ Cin $=$ Cincinnati $;$ Tuc $=$ Tucson; NYC $=$ New York City $;$ Law $=$ Lawrence; Gr.F $=$ Grand Forks; Tr.P $=$ Terrace Park.

The EPA National Organics Reconnaissance Survey (NORS) confirmed the widespread presence of many organics. NORS found as many as 129 organic compounds, attributable to industrial, agricultural, and municipal sources, in finished drinking water supplies that passed through conventional (filtration and chlorination) water treatment equipment [12]. These compounds include carbon tetrachloride and 1,2-dichloroethane. One chemical was present in far higher concentrations than any other - chloroform and its related family members the trihalomethanes. It has been shown that chlorination of raw water in drinking water treatment plants produces such compounds as chloroform, carbon tetrachloride, chlorinated bromomethanes, and other compounds [3,4]. Table 2 lists some additional carcinogens found in drinking water from a limited survey in 1976 and 1977 [13]. Domestic sewage plants also constitute a source of chlorinated hydrocarbons. These compounds are not significantly broken down by conventional waste treatment and pass through most plants unaffected. Chlorination of the domestic sewage also results in the generation of a mixture of chlorinated hydrocarbons [14]. 
In addition, the effects of drinking water contaminants may be potentiated by other exposures to carcinogens and promoters (e.g. from food, air pollution, and smoking), a particular problem for people living in urban areas or exposed to occupational carcinogens.

Drinking water contamination has been consistently linked to gastrointestinal (GI) and urinary tract (UT) cancer, although association with other sites (e.g. lung, brain) have been observed. Mutagens are a suspected causal factor in atherosclerosis, and they are capable of causing subtle biological changes, some of which may affect health today in unknown ways, and some of which may not be expressed for several generations. Even less is known about the extent to which drinking contaminants may contribute to fetal deaths, stunted growth and birth defects, although a recent study suggests this may be a potential problem [14].

The National Organics Monitoring Survey investigated 113 water systems and also found carbon tetrachloride, benzene, trichloroethylene, vinyl chloride, and styrene. These and other data clearly demonstrate that synthetic organic chemical contamination in many of the nation's drinking water supplies is a reality. Although the proposed regulations distinguish between trihalomethanes (THMs) and other organics, contaminated surface waters are likely to contain certain amounts of both types of organics [15].

Given this record of exposure in drinking water, the cause for concern on the part of drinking water managers, regulators, public health officials, customers and others is reasonable. In the following section some of the human health considerations are examined.

\section{HUMAN HEALTH CONSIDERATIONS}

Organic contaminants may pose a potential threat to health today and in the future. The effects of exposure to carcinogens have a typically long latency; the time elapsing between exposure and clinical symptoms of the disease is often as much as 20-40 years, depending upon the level of exposure [13].

In 1981 about 805000 people were diagnosed as having cancer (excluding skin cancer) with approximately one-third surviving at least 5 years after treatment. Gastrointestinal and urinary tract cancers, to which organic drinking water contaminants have been most consistently linked, comprise about $30 \%$ of the total cancer illnesses and deaths annually [16].

Unfortunately, the total risk associated with exposure to multiple carcinogens may be far greater than the sum of the risks posed by each chemical individually, due to synergistic interactions between carcinogens. Exposure to promoters might also enhance the carcinogenic effect of chemicals in drinking water compared with the effect of single chemicals in rodent studies. A single promoter has been shown to intensify the effects of a particular carcinogen by a factor of 1000 [13]. Additionally, the effects of drinking water contaminants may be potentiated by other exposures to 


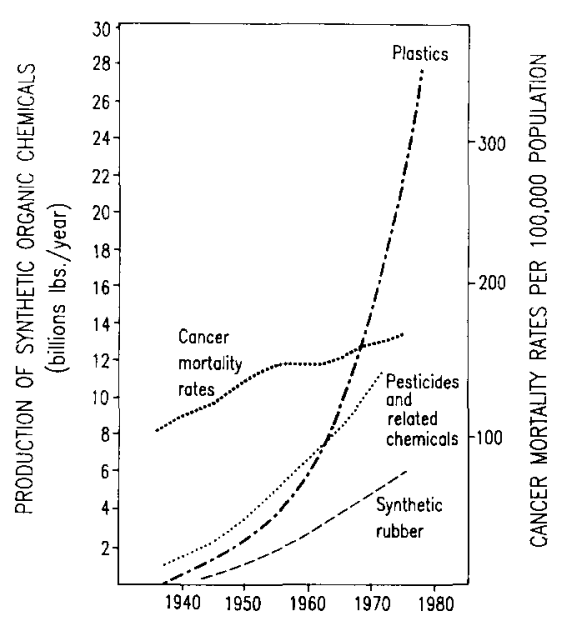

Fig. 1. Cancer mortality rates and chemical production as a function of time.

carcinogens and promoters, especially for people living in urban areas or exposed to occupational carcinogens. As has been mentioned earlier, drinking water contamination has been consistently linked to gastrointestinal (GI) and urinary tract (UT) cancer, although association with other sites (e.g. lung, brain) have been observed $[16,17]$.

While efforts are continually being made to estimate the risks to human health posed by these chemicals, such estimates are highly uncertain. Both means of determining cancer risks - animal experiments and human epidemiologic studies - have considerable limitations, and the methodologies used to establish mutagenic and teratogenic effects may be even less applicable to man than animal cancer tests [18].

The list of studies could go on for many pages and will be discussed later, yet the results are never the same. Most find some level of significant relationship but there are usually as many as there are reports and methodologies. Unfortunately, the epidemiological studies do not distinguish the possible effects of THMs from those of synthetic organics which may have been present. While water has been chlorinated since the early $1900 \mathrm{~s}$, many synthetic organics are of recent origin. During the "chemical revolution" of the past 30 years, the annual production of synthetic organic chemicals increased from approximately 5 billion to 50 billion pounds per year. Many of these chemicals have never been found anywhere else in nature. Given a probable 20-40 year latency for most chemical carcinogens, it is likely that most of the effect of synthetic organics are not yet expressed in total U.S. cancer rates (Fig. 1). Hence, currently observed excess cancers demonstrated in epidemiologic studies may be primarily the result of chlorination byproducts and may not reflect the risk from exposure to current levels of synthetic organics [13]. These epidemiological studies are discussed in the following section. 


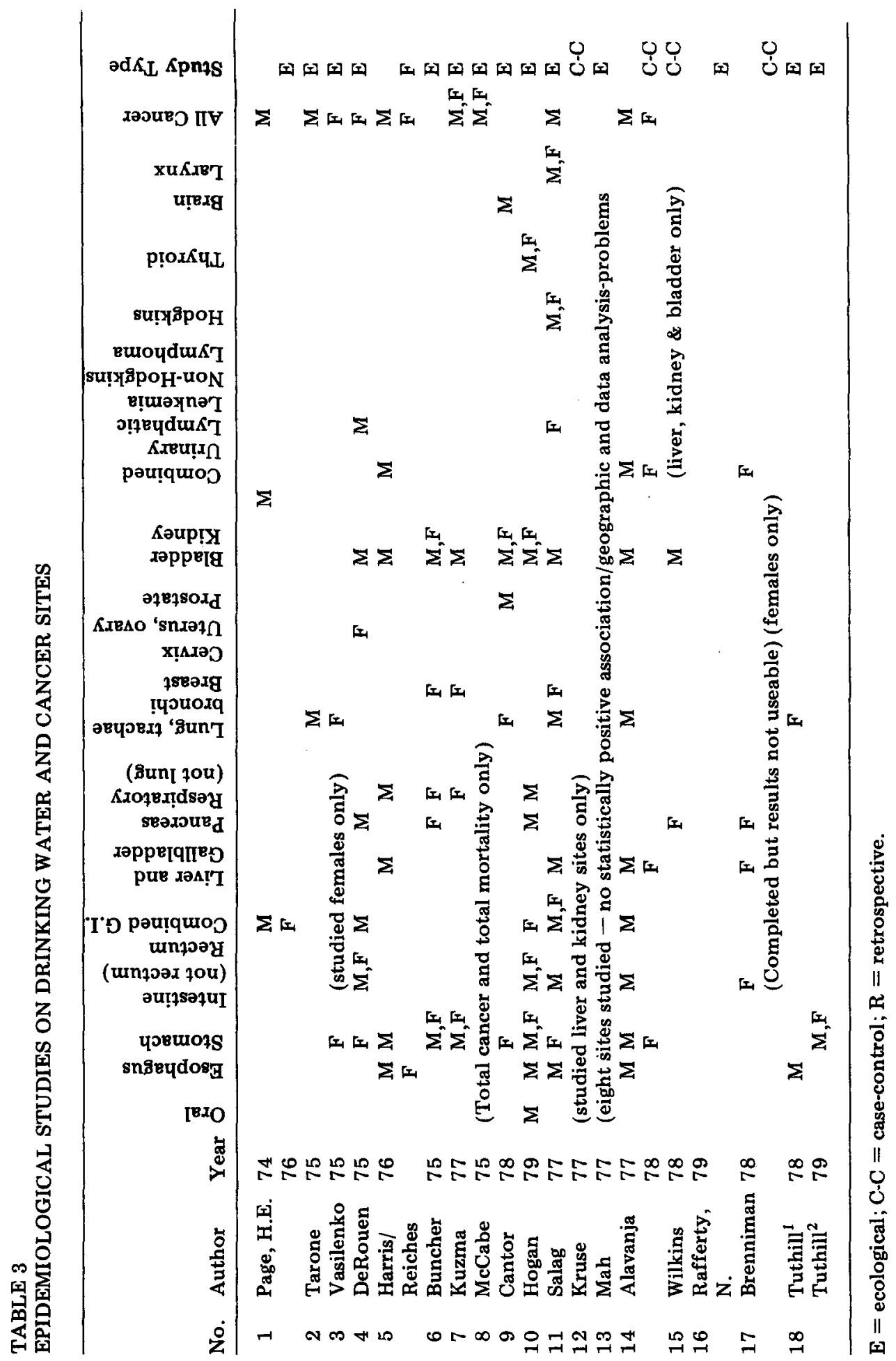




\section{RESULTS OF EPIDEMIOLOGICAL STUDIES}

By August, 1979, 18 epidemiological studies, and additional unpublished reports, discussed possible relationships between cancer mortality and morbidity and drinking water supplies [10]. The results of the studies are shown in Table 3 in the approximate chronological order of completion. The table shows the statistically significant results of analysis by anatomical site. The statistically significant positive results are denoted by " $M$ " for males and " $F$ " for females and the statistically significant negative results are denoted by "-" before the "M" and " $F$ ".

Five of the studies were published through August, 1979. All of the studies were retrospective in design; 16 were correlation studies, and four used a case-control approach. Four studies utilized cancer morbidity or incidence rather than mortality as a measure of disease frequency. The studies vary in sample size, cancer sites considered, factors selected as possible explanatory variables, parameters selected as indicators of water quality, and in the statistical techniques used for analysis, so caution must be used in comparing the results of one study with the results of another study.

The water quality data are recent, and it is not known to what extent they reflect past exposure to THMs. This is important, since the latent period for most types of cancer is measured in decades. Comparison of the various study results is also difficult because of the different approaches used.

In general, retrospective epidemiological studies are a useful methodological tool in hypothesis generation. The results from these studies, when viewed collectively, can provide some insight into the postulation of causal relationships which then need to be tested further, using epidemiological designs such as case-control or cohort studies, for documentation.

When the evidence from all studies is weighed, an emphasis can be placed not only on the statistical significance of single correlation coefficients but on their consistency and patterns. When more than one independent study shows positive associations for site-specific cancers, then the association may not be due to chance alone. When the association is verified by consistent results across all four sex-race groups (white male, non-white male, white female, non-white female), the association is more likely to be due to the variable considered and the evidence should be viewed more seriously. The studies done so far suggest the appropriateness of concern.

The evidence thus far is incomplete and the trends and patterns of association have not been fully developed. A causal relationship cannot be established by correlation studies. But when viewed collectively, the epidemiological studies completed thus far provide evidence for maintaining a hypothesis that there may be a health risk and that the positive correlations may be due to an association between some constituents of drinking water and cancer mortality. Animal test data results alone provide a firm basis for policy decision making. Additional epidemiological studies may provide evidence regarding the strength of the associations and the possibility of a causal 
TABLE 4

CARCINOGENS, MUTAGENS AND PROMOTERS FOUND IN UNITED STATES DRINKING WATER

Carcinogens and suspect carcinogens

Benzo [a] pyrene
Carbon tetrachloride
Chloroform
Vinyl chloride
1, 4-Dioxane
Methyl iodide
DDE
DDT
Chlordane
Lindane
Dieldrin
Benzene

Mutagens and suspect mutagens

1, 1, -trichloroethane
Bromomethane (methyl bromide)
Methyl chloride
Bromochloromethane
Methylene chloride
Bromoform
Bromodichloromethane
2-Chloropropane
1, 2-Dichloropropane
1-Chloropropene
1, 2-Dichloroethane recently shown
to be carcinogenic by NCI
Bis (2-chloroisopropyl) ether
Chlorodibromomethane
1, 3-Dichloropropene
2, 6-Dinitrotoluene

Promoters

Ortho-cresol

2, 4-Dimethylphenol

Phenol

n-Dodecane

Eicasane

2, 4-Dichlorophenol

\author{
Vinylidene chloride \\ Heptachlor \\ 1, 1, 2-Trichloroethane \\ 1, 1, 2-Trichloroethylene \\ Bis (2-choroethyl) ether \\ Simazine \\ Tetrachloroethylene \\ Heptachlor epoxie \\ Acrylonitrile \\ Aldrin \\ Butyl bromide
}

\author{
Dichloroacetonitrile \\ Methylene bromide \\ Chlordane \\ Vinylidene chloride \\ n-Butylbromide \\ Bis (2-chloroethyl) ether \\ Acrylonitrile \\ Benzo [a] pyrene \\ Methyl iodide \\ Vinyl chloride \\ 1, 2-Bis (chloroethoxy) ethane
}

Pyrene

1, 1, 2-Trichloroethylene

Tetrachloroethylene (perchloroethylene)

n-Decane

Limnonene

Octadecane

n-Tetradecane

n-Undecane

Source: National Cancer Institute, May 1978.

relationship between drinking water and cancer mortality, and thus provide a stronger basis for further regulatory action.

The NAS Epidemiology Subcommittee of the Safe Drinking Water Committee reviewed the first 13 of the aforementioned 18 studies. In the report, "Epidemiological Studies of Cancer Frequency and Certain Organic Constituents of Drinking Water - A Review of Recent Literature Published and 
Unpublished", September 1978, the committee reached the following conclusions, which are consistent with EPA. Along with the group of studies that characterized water quality by actual measurements, the results suggest:

\footnotetext{
"That higher concentrations of THMs in drinking water may be associated with an increased frequency of cancer of the bladder. The results do not establish causality, and the quantitative estimates of increased or decreased risk are extremely crude. The positive association found for bladder cancer was small and had a large margin of error; not only statistical, but much more importantly, because of the very nature of the studies." [18]
}

There are several problems which make the results difficult to interpret: (1) there is limited water quality data on organics and other contaminants in the finished drinking water, and the data on organics and other contaminants in the finished drinking water, and the data which exist cover less than 5 years; and (2) the water quality data are often from geographic areas other than those (usually counties) reporting cancer mortality data [10]. Table 4 contains a list of carcinogens and promoters found in drinking water in the U.S.

Before passage of the Safe Drinking Water Act, the traditional method of measuring organics in drinking water has been to measure the concentration of some general organic parameter such as carbon chloroform extract (CCE). The Safe Drinking Water Act has focused interest on measuring individual organics in finished water. The typical method for evaluating the concentration of these individual organics in water has been to concentrate these compounds into an organic solvent by liquid-liquid extraction, reduce the volume of the solvent to a small quantity by heating and inject an aliquot of this material into a gas chromatograph. This approach is both difficult and expensive $[19,20]$.

Another problem of using specific individual organic compounds is, as implied earlier, the lack of analyses of the interaction of organic compounds and the impact of exposure of the human body to a total body burden of organics. In an attempt to recognize this "total" affect an analysis has been made of carbon chloroform extract (CCE) and carbon alcohol extract (CAE) and its relationship to cancer mortality.

\section{CANCER DEATH RATE VERSUS TOTAL ORGANICS}

Carbon chloroform extract (CCE) and carbon alcohol extract (CAE) have been monitored for varying periods between 1957 and 1972 at 129 stations throughout the U.S. by the Water Pollution Surveillance System and its predecessor, the National Water Quality Network, and the resulting data were stored in STORET. Unfortunately, two different techniques were used to collect the data, but all of the data have been converted into a common base and these data are shown in Table 5 [21].

The monitoring procedures for organic contaminants discussed here involved two variations of the carbon adsorption method (CAM): the high-flow CAM (CAM-hf), which was developed in the early 1950s and is applicable to 
TABLE 5

CCE AND CAE DATA FROM WATER SURVEILLANCE SYSTEM

\begin{tabular}{|c|c|c|c|c|c|c|c|c|}
\hline \multirow{2}{*}{$\begin{array}{l}\text { STORET } \\
\text { No. }\end{array}$} & \multirow{2}{*}{$\begin{array}{l}\text { Period of } \\
\text { record }\end{array}$} & \multirow{2}{*}{$\begin{array}{l}\text { Area served } \\
\text { by water } \\
\text { source }\end{array}$} & \multirow{2}{*}{$\mathrm{CCE}$} & \multirow{2}{*}{ CAE } & \multicolumn{2}{|c|}{$\begin{array}{l}\text { GI-UT cancer } \\
\text { rates }(100000)\end{array}$} & \multicolumn{2}{|c|}{$\begin{array}{l}\text { All cancer sites } \\
\text { deaths }(100000)\end{array}$} \\
\hline & & & & & $\begin{array}{l}\text { Male } \\
\text { white }\end{array}$ & $\begin{array}{l}\text { Female } \\
\text { white }\end{array}$ & $\begin{array}{l}\text { Male } \\
\text { white }\end{array}$ & $\begin{array}{l}\text { Female } \\
\text { white }\end{array}$ \\
\hline 010077 & $1960-69$ & & 108.0 & 33.0 & 46.0 & 30.6 & 124.6 & 102.3 \\
\hline 010120 & $1962-68$ & & 149.0 & 223.0 & 56.9 & 38.7 & 136.5 & 111.5 \\
\hline 030030 & $1956-67$ & & 110.0 & 811.0 & 60.7 & 44,0 & 154.2 & 112.2 \\
\hline 030060 & $1959-71$ & & 76.0 & 769.0 & 65.2 & 43.4 & 133.1 & 93.1 \\
\hline \multirow[t]{2}{*}{040022} & $1958-69$ & & 117.0 & 492.0 & & & & \\
\hline & & $\begin{array}{l}\text { Area } 1 \\
\text { Area } 2\end{array}$ & & & $\begin{array}{l}63.7 \\
79.5\end{array}$ & $\begin{array}{l}36.6 \\
49.5\end{array}$ & $\begin{array}{l}183.6 \\
188.8\end{array}$ & $\begin{array}{l}199.9 \\
128.9\end{array}$ \\
\hline \multirow[t]{2}{*}{040043} & 1959 & & 87.9 & 489.0 & & & & \\
\hline & & $\begin{array}{l}\text { Area } 1 \\
\text { Area } 2\end{array}$ & & & $\begin{array}{l}54.9 \\
53.3\end{array}$ & $\begin{array}{l}44.9 \\
47.3\end{array}$ & $\begin{array}{r}1138.7 \\
152.4\end{array}$ & $\begin{array}{l}110.2 \\
119.4\end{array}$ \\
\hline \multirow[t]{2}{*}{040052} & 1959 & & 182.0 & 594.0 & & & & \\
\hline & & $\begin{array}{l}\text { Area } 1 \\
\text { Area } 2\end{array}$ & & & $\begin{array}{l}54.9 \\
53.3\end{array}$ & $\begin{array}{l}44.9 \\
47.3\end{array}$ & $\begin{array}{l}138.7 \\
152.4\end{array}$ & $\begin{array}{l}110.2 \\
119.4\end{array}$ \\
\hline \multirow[t]{2}{*}{050004} & $\begin{array}{l}1963-65 \\
1958-70\end{array}$ & & $\begin{array}{l}131.0 \\
122.0\end{array}$ & $\begin{array}{l}858.0 \\
420.0\end{array}$ & 63.8 & 44.3 & 171.7 & 120.3 \\
\hline & & $\begin{array}{l}\text { Area } 1 \\
\text { Area } 2\end{array}$ & & & $\begin{array}{l}65.5 \\
59.4\end{array}$ & $\begin{array}{l}46.4 \\
34.4\end{array}$ & $\begin{array}{l}159.5 \\
129.4\end{array}$ & $\begin{array}{r}121.9 \\
83.3\end{array}$ \\
\hline \multirow[t]{2}{*}{$\begin{array}{l}050088 \\
050116\end{array}$} & $\begin{array}{l}1961-69 \\
1962-69\end{array}$ & & $\begin{array}{l}57.0 \\
87.0\end{array}$ & $\begin{array}{l}322.0 \\
435.0\end{array}$ & 76.0 & 48.1 & 174.8 & 123.1 \\
\hline & & $\begin{array}{l}\text { Area } 1 \\
\text { Area } 2\end{array}$ & & & $\begin{array}{l}77.8 \\
66.9\end{array}$ & $\begin{array}{l}59.6 \\
48.5\end{array}$ & $\begin{array}{l}187.2 \\
171.9\end{array}$ & $\begin{array}{l}131.3 \\
127.3\end{array}$ \\
\hline 050122 & $1962-68$ & & 149.0 & 797.0 & 61.0 & 42.2 & 155.6 & 110.4 \\
\hline 070006 & 1962 & & 248.0 & 384.0 & 65.8 & 48.4 & 140.8 & 106.3 \\
\hline 060092 & $1961-65$ & & 99.0 & 688.0 & 66.1 & 41.0 & 151.5 & 108.8 \\
\hline 100130 & $1963-69$ & & 186.0 & 574.0 & 88.0 & 54.9 & 204.7 & 142.7 \\
\hline \multirow[t]{5}{*}{110057} & $1960-69$ & & 95.0 & 216.0 & & & & \\
\hline & & Area 1 & & & 45.2 & 27.6 & 92.2 & 76.3 \\
\hline & & Area 2 & & & 59.0 & 33.9 & 128.9 & 96.9 \\
\hline & & Area 3 & & & 52.2 & 44.3 & 148.9 & 112.9 \\
\hline & & Area 4 & & & 29.3 & 37.2 & 83.8 & 112,7 \\
\hline \multirow[t]{3}{*}{110062} & $1960-66$ & & 185.0 & 667.0 & & & & \\
\hline & & Area 1 & & & 58.6 & 42.2 & 172.6 & 118.8 \\
\hline & $1958-68$ & Area 2 & 182.0 & 1158.0 & 58.5 & 38.5 & 134.5 & 92.9 \\
\hline \multirow{2}{*}{120047} & & Area 1 & & & 71.5 & 47.5 & 172.7 & 125.4 \\
\hline & & Area 2 & & & 734 & 449 & 171.4 & 198.8 \\
\hline \multirow[t]{3}{*}{120058} & $1960-68$ & & 145.0 & 444.0 & & & & \\
\hline & & Area 1 & & & 67.2 & 45.3 & 187.2 & 139.3 \\
\hline & & Area 2 & & & 61.9 & 38.5 & 169.5 & 111.6 \\
\hline \multirow[t]{3}{*}{120059} & $1959-68$ & & 223.0 & 463.0 & & & & \\
\hline & & Area 1 & & & 68.4 & 39.5 & 176.9 & 114.9 \\
\hline & & Area 2 & & & 58.9 & 48.2 & 167.8 & 139.5 \\
\hline 120135 & $1964-68$ & & 212.0 & 592.0 & 62.1 & 45.4 & 160.8 & 122.4 \\
\hline 150097 & $1961-68$ & & 133.0 & 409.0 & & & & \\
\hline
\end{tabular}

(continued) 
TABLE 5 (continued)

\begin{tabular}{|c|c|c|c|c|c|c|c|c|}
\hline \multirow{2}{*}{$\begin{array}{l}\text { STORET } \\
\text { No. }\end{array}$} & \multirow{2}{*}{$\begin{array}{l}\text { Period of } \\
\text { record }\end{array}$} & \multirow{2}{*}{$\begin{array}{l}\text { Area served } \\
\text { by water } \\
\text { source }\end{array}$} & \multirow{2}{*}{$\mathrm{CCE}$} & \multirow{2}{*}{$\mathrm{CAE}$} & \multicolumn{2}{|c|}{$\begin{array}{l}\text { GI-UT cancer } \\
\text { rates }(100000)\end{array}$} & \multicolumn{2}{|c|}{$\begin{array}{l}\text { All cancer sites } \\
\text { deaths }(100000)\end{array}$} \\
\hline & & & & & $\begin{array}{l}\text { Male } \\
\text { white }\end{array}$ & $\begin{array}{l}\text { Female } \\
\text { white }\end{array}$ & $\begin{array}{l}\text { Male } \\
\text { white }\end{array}$ & $\begin{array}{l}\text { Female } \\
\text { white }\end{array}$ \\
\hline & & Area 1 & & & 67.6 & 54.7 & 151.4 & 128.1 \\
\hline & & Area 2 & & & 65.4 & 38.3 & 143.1 & 194.4 \\
\hline \multirow[t]{3}{*}{150102} & $1957-64$ & & 133.0 & 626.0 & & & & \\
\hline & & Area 1 & & & 51.3 & 49.4 & 128.1 & 100.7 \\
\hline & & Area 2 & & & 55.7 & 39.2 & 141.2 & 95.4 \\
\hline 105113 & $1962-67$ & & 37.0 & 120.0 & 64.1 & 48.0 & 135.1 & 116.6 \\
\hline 105114 & $1962-69$ & & 57.0 & 175.0 & 60.8 & 44.3 & 140.0 & 121.0 \\
\hline 105125 & $1962-69$ & & 95.0 & 623.0 & 48.1 & 43.9 & 102.3 & 104.4 \\
\hline \multirow[t]{4}{*}{160024} & $1957-70$ & & 212.0 & 894.0 & & & & \\
\hline & & Area 1 & & & 82.8 & 55.9 & 197.9 & 139.7 \\
\hline & & Area 2 & & & 77.2 & 59.5 & 176.2 & 126.2 \\
\hline & & Area 3 & & & 79.2 & 53.5 & 182.5 & 133.9 \\
\hline \multirow[t]{3}{*}{$\begin{array}{l}160035 \\
160067\end{array}$} & $\begin{array}{l}1958-72 \\
1960-72\end{array}$ & & $\begin{array}{l}151.0 \\
429.0\end{array}$ & $\begin{array}{l}597.0 \\
145.0\end{array}$ & 55.1 & 45.9 & 138.2 & 119.4 \\
\hline & & Area 1 & & & 76.2 & 53.2 & 178.5 & 133.4 \\
\hline & & Area 2 & & & 73.7 & 51.1 & 179.2 & 127.8 \\
\hline \multirow[t]{3}{*}{69098} & $1961-62$ & & 187.0 & 778.0 & & & & \\
\hline & & Area 1 & & & 65.6 & 55.1 & 164.3 & 139.5 \\
\hline & & Area 2 & & & 49.8 & 36.9 & 120.4 & 96.6 \\
\hline \multirow{4}{*}{$\begin{array}{l}170017 \\
170036\end{array}$} & $1958-69$ & & 50.0 & 199.0 & 93.4 & 57.1 & 199.4 & 142.9 \\
\hline & $1958-72$ & & 222.0 & 687.0 & & & & \\
\hline & & Area 1 & & & 75.4 & 52.9 & 174.7 & 136.2 \\
\hline & & Area 2 & & & 64.6 & 39.6 & 155.5 & 116.5 \\
\hline \multirow{3}{*}{79105} & $1962-71$ & & 183.0 & 694.0 & & & & \\
\hline & & Area 1 & & & 79.7 & 57.1 & 164.0 & 124.8 \\
\hline & & Area 2 & & & 64.3 & 49.2 & 148.5 & 125.6 \\
\hline \multirow[t]{3}{*}{180025} & $1957-72$ & & 185.0 & 848.0 & & & & \\
\hline & & Area 1 & & & 76.9 & 50.0 & 164.8 & 128.8 \\
\hline & & Area 2 & & & 51.4 & 51.7 & 139.6 & 115.8 \\
\hline \multirow[t]{4}{*}{180026} & $1957-72$ & & 209.0 & 858.0 & & & & \\
\hline & & Area 1 & & & 85.3 & 56.5 & 192.2 & 144.9 \\
\hline & & Area 2 & & & 73.2 & 54.9 & 162.4 & 129.9 \\
\hline & & Area 3 & & & 67.6 & 53.9 & 152.8 & 125.4 \\
\hline \multirow[t]{3}{*}{190002} & $1959-63$ & & 110.0 & 825.0 & & & & \\
\hline & & Area 1 & & & 39.4 & 21.0 & 123.1 & 96.9 \\
\hline & & Area 2 & & & 61.9 & 50.1 & 115.6 & 124.4 \\
\hline \multirow[t]{3}{*}{910029} & $1957-70$ & & 113.0 & 584.0 & & & & \\
\hline & & Area 1 & & & 75.5 & 48.9 & 181.5 & 131.9 \\
\hline & & Area 2 & & & 75.9 & 48.9 & 183.0 & 140.2 \\
\hline \multirow[t]{3}{*}{190128} & $1962-69$ & & 92.0 & 416.0 & & & & \\
\hline & & Area 1 & & & 61.9 & 42.5 & 145.4 & 114.1 \\
\hline & & Area 2 & & & 58.1 & 49.8 & 129.9 & 129.9 \\
\hline \multirow[t]{3}{*}{200084} & $1961-71$ & & 200.0 & 776.0 & & & & \\
\hline & & Area 1 & & & 74.5 & 52.9 & 185.0 & 131.4 \\
\hline & & Area 2 & & & 68.1 & 48.6 & 163.6 & 121.5 \\
\hline 210020 & $1958-71$ & & 124.0 & 573.0 & & & & \\
\hline
\end{tabular}




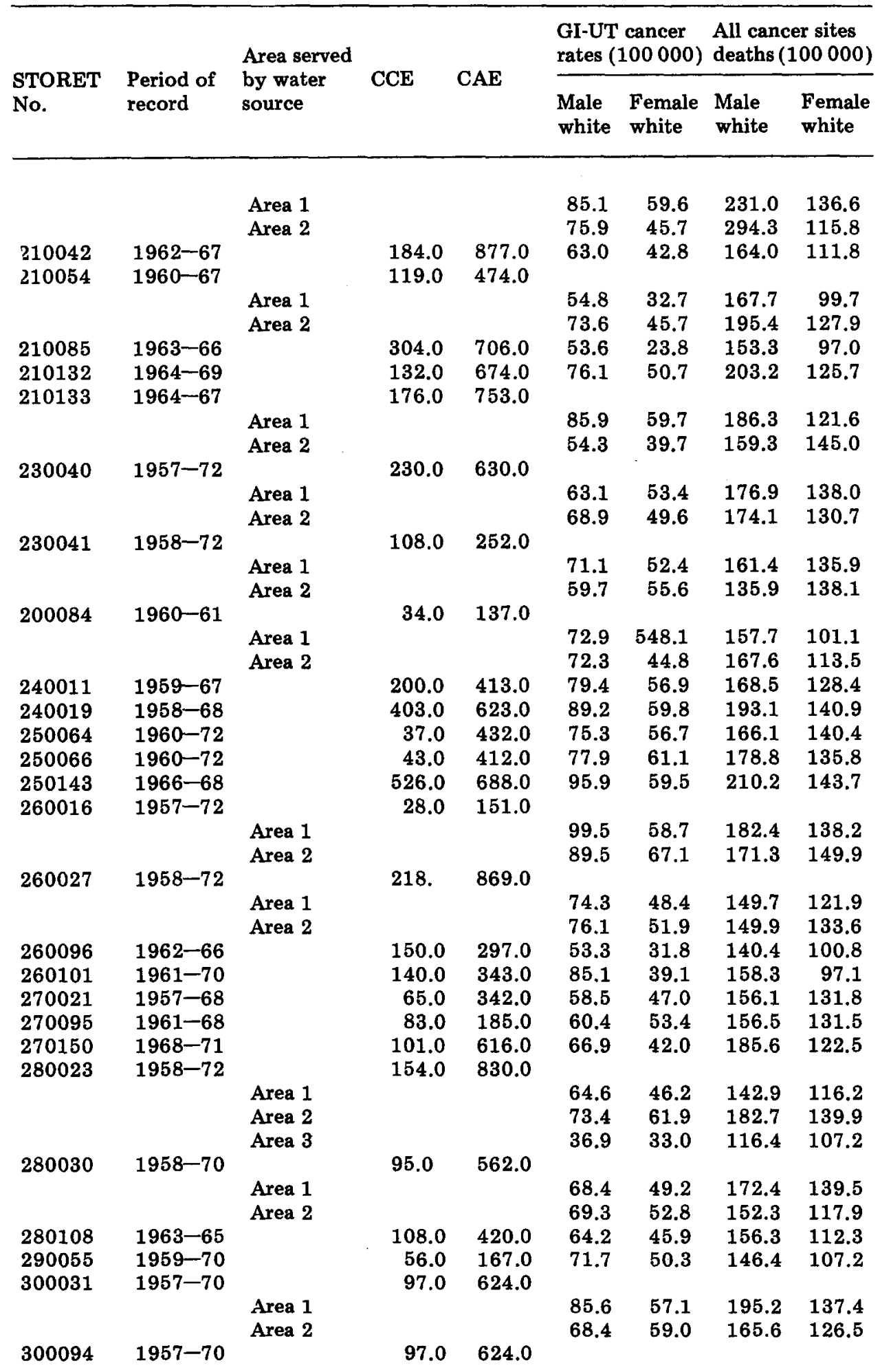

(continued) 
TABLE 5 (continued)

\begin{tabular}{|c|c|c|c|c|c|c|c|c|}
\hline \multirow{2}{*}{$\begin{array}{l}\text { STORET } \\
\text { No. }\end{array}$} & \multirow{2}{*}{$\begin{array}{l}\text { Period of } \\
\text { record }\end{array}$} & \multirow{2}{*}{$\begin{array}{l}\text { Area served } \\
\text { by water } \\
\text { source }\end{array}$} & \multirow{2}{*}{ CCE } & \multirow{2}{*}{ CAE } & \multicolumn{2}{|c|}{$\begin{array}{l}\text { GI-UT cancer } \\
\text { rates }(100000)\end{array}$} & \multicolumn{2}{|c|}{$\begin{array}{l}\text { All cancer sites } \\
\text { deaths }(100000)\end{array}$} \\
\hline & & & & & $\begin{array}{l}\text { Male } \\
\text { white }\end{array}$ & $\begin{array}{l}\text { Female } \\
\text { white }\end{array}$ & $\begin{array}{l}\text { Male } \\
\text { white }\end{array}$ & $\begin{array}{l}\text { Female } \\
\text { white }\end{array}$ \\
\hline & & Area 1 & & & 85.6 & 57.1 & 195.2 & 137.4 \\
\hline & & Area 2 & & & 68.4 & 59.0 & 164.6 & 126.5 \\
\hline 310005 & $1958-71$ & & 73.0 & 322.0 & 67.3 & 45.3 & 168.5 & 113.9 \\
\hline \multirow[t]{3}{*}{330100} & $1963-69$ & & 189.0 & 613.0 & & & & \\
\hline & & Area 1 & & & 190.7 & 63.2 & 206.4 & 146.2 \\
\hline & & Area 2 & & & 78.5 & 56.6 & 175.2 & 132.4 \\
\hline \multirow[t]{3}{*}{331123} & $1962-69$ & & \multicolumn{2}{|c|}{372.015290 .0} & & & & \\
\hline & & Area 1 & & & 194.3 & 66.8 & 221.8 & 150.2 \\
\hline & & Area 2 & & & 194.9 & 69.3 & 216.6 & 160.8 \\
\hline 340093 & $1961-64$ & & 106.0 & 387.0 & 47.4 & 34.9 & 115.8 & 84.9 \\
\hline 340056 & $1960-65$ & & 59.0 & 202.0 & 56.9 & 46.1 & 131.3 & 115.7 \\
\hline 350014 & $1965-71$ & & 124.0 & 513.0 & 96.8 & 58.9 & 208.0 & 143.3 \\
\hline \multirow[t]{3}{*}{350018} & $1958-69$ & & 193.0 & 965.0 & & & & \\
\hline & & Area 1 & & & 75.9 & 52.2 & 167.5 & 119.5 \\
\hline & & Area 2 & & & 85.6 & 69.2 & 194.4 & 145.3 \\
\hline \multirow{4}{*}{$\begin{array}{l}350063 \\
359014\end{array}$} & $1961-71$ & & 94.0 & 553.0 & 69.2 & 50.7 & 156.3 & 130.8 \\
\hline & $1964-69$ & & 302.0 & 16692.0 & & & & \\
\hline & & Area 1 & & & 199.0 & 69.8 & 232.8 & 154.5 \\
\hline & & Area 2 & & & 199.9 & 69.3 & 216.6 & 160.8 \\
\hline \multirow[t]{3}{*}{370033} & $1958-70$ & & 94.0 & 372.0 & & & & \\
\hline & & Area 1 & & & 76.4 & 52.4 & 169.2 & 126.4 \\
\hline & & Area 2 & & & 73.3 & 48.7 & 158.5 & 115.4 \\
\hline \multirow{4}{*}{$\begin{array}{l}370034 \\
370069\end{array}$} & $1957-69$ & & 65.0 & 279.0 & 68.4 & 47.1 & 143.5 & 122.4 \\
\hline & $1960-70$ & & 131.0 & 510.0 & & & & \\
\hline & & Area 1 & & & 68.2 & 59.3 & 141.2 & 116.7 \\
\hline & & Area 2 & & & 66.8 & 49.1 & 144.6 & 126.7 \\
\hline \multirow[t]{4}{*}{380090} & $1960-68$ & & 229.0 & 767.0 & & & & \\
\hline & & Area 1 & & & 99.1 & 59.3 & 204.8 & 149.1 \\
\hline & & Area 2 & & & 86.1 & 626 & 294.6 & 153.9 \\
\hline & & Area 3 & & & 82.5 & 58.3 & 297.2 & 159.9 \\
\hline \multirow[t]{3}{*}{380039} & $1957-61$ & & 326.0 & 644.0 & & & & \\
\hline & & Area 1 & & & 74.5 & 69.1 & 172.7 & 139.2 \\
\hline & & Area 2 & & & 82.7 & 56.8 & 291.7 & 138.4 \\
\hline \multirow[t]{3}{*}{380117} & $1962-72$ & & 244.0 & 756.0 & & & & \\
\hline & & Area 1 & & & 69.5 & 43.9 & 141.9 & 110.5 \\
\hline & & Area 2 & & & 68.6 & 47.3 & 153.9 & 119.1 \\
\hline 380126 & $1963-70$ & & 1590.0 & 1980.0 & 98.3 & 60.8 & 212.9 & 147.6 \\
\hline 390001 & $1958-62$ & & 234.0 & 474.0 & 63.9 & 49.3 & 160.0 & 120.4 \\
\hline 390109 & $1962-71$ & & 207.0 & 492.0 & 61.0 & 49.1 & 151.7 & 125.7 \\
\hline 400007 & $1958-67$ & & 96.0 & 304.0 & 66.1 & 48.4 & 156.9 & 126.1 \\
\hline 400008 & $1957-69$ & & 36.0 & 124.0 & 63.3 & 44.4 & 156.7 & 117.2 \\
\hline 400078 & $1961-68$ & & 250.0 & 1150.0 & 68.6 & 50.9 & 148.9 & 121.8 \\
\hline 400081 & $1961-68$ & & 70.0 & 275.0 & 62.6 & 46.7 & 145.7 & 127.7 \\
\hline 400124 & $1963-68$ & & 127.0 & 473.0 & 76.7 & 48.9 & 179.4 & 130.1 \\
\hline 410012 & $1957-65$ & & 536.0 & 976.0 & 87.1 & 60.0 & 192.1 & 142.8 \\
\hline \multirow[t]{3}{*}{410061} & $1959-69$ & & 106.0 & 521.0 & & & & \\
\hline & & Area 1 & & & 99.4 & 57.2 & 188.5 & 135.1 \\
\hline & & Area 2 & & & 99.9 & 60.9 & 190.3 & 148.7 \\
\hline $\begin{array}{l}410074 \\
410076\end{array}$ & $\begin{array}{l}1960-69 \\
1960-72\end{array}$ & & $\begin{array}{r}330.0 \\
97.0\end{array}$ & $\begin{array}{l}868.0 \\
268.0\end{array}$ & 78.1 & 55.1 & 176.1 & 134.1 \\
\hline
\end{tabular}




\begin{tabular}{|c|c|c|c|c|c|c|c|c|}
\hline \multirow{2}{*}{$\begin{array}{l}\text { STORET } \\
\text { No. }\end{array}$} & \multirow{2}{*}{$\begin{array}{l}\text { Period of } \\
\text { record }\end{array}$} & \multirow{2}{*}{$\begin{array}{l}\text { Area served } \\
\text { by water } \\
\text { source }\end{array}$} & \multirow{2}{*}{ CCE } & \multirow{2}{*}{ CAE } & \multicolumn{2}{|c|}{$\begin{array}{l}\text { GI-UT cancer } \\
\text { rates }(100000)\end{array}$} & \multicolumn{2}{|c|}{$\begin{array}{l}\text { All cancer sites } \\
\text { deaths }(100000)\end{array}$} \\
\hline & & & & & $\begin{array}{l}\text { Male } \\
\text { white }\end{array}$ & $\begin{array}{l}\text { Female } \\
\text { white }\end{array}$ & $\begin{array}{l}\text { Male } \\
\text { white }\end{array}$ & $\begin{array}{l}\text { Female } \\
\text { white }\end{array}$ \\
\hline & & Area 1 & & & 72.5 & 59.3 & 155.9 & 132.2 \\
\hline & & Area 2 & & & 73.3 & 55.6 & 192.5 & 137.7 \\
\hline 410079 & $1961-72$ & & 274.0 & 464.0 & 93.8 & 61.5 & 203.1 & 144.1 \\
\hline \multirow[t]{3}{*}{450048} & $1958-70$ & & 185.0 & 478.0 & & & & \\
\hline & & Area 1 & & & 61.8 & 43.8 & 168.1 & 125.8 \\
\hline & & Area 2 & & & 66.8 & 49.6 & 187.4 & 120.6 \\
\hline \multirow[t]{3}{*}{460032} & $1957-70$ & & 88.0 & 449.0 & & & & \\
\hline & & Area 1 & & & 55.4 & 43.2 & 121.3 & 195.1 \\
\hline & & Area 2 & & & 62.3 & 54.1 & 132.5 & 127.8 \\
\hline 460080 & $1966-70$ & & 619.0 & 2360.0 & 80.1 & 51.9 & 170.7 & 129.9 \\
\hline 470051 & $1958-68$ & & 112.0 & 403.0 & 60.3 & 47.5 & 164.3 & 125.8 \\
\hline \multirow[t]{3}{*}{470099} & $1958-68$ & & 142.0 & 478.0 & & & & \\
\hline & & Area 1 & & & 42.7 & 38.8 & 132.8 & 192.1 \\
\hline & & Area 2 & & & 47.9 & 42.5 & 129.1 & 121.1 \\
\hline 470016 & $1961-68$ & & 52.0 & 181.0 & 58.0 & 45.7 & 155.4 & 121.2 \\
\hline 470017 & $1962-68$ & & 78.0 & 139.0 & 52.3 & 41.9 & 140.4 & 117.9 \\
\hline \multirow{3}{*}{470044} & $1962-68$ & & 158.0 & 550.0 & & & & \\
\hline & & Area 1 & & & 56.8 & 52.9 & 149.9 & 199.3 \\
\hline & & Area 2 & & & 48.1 & 42.3 & 147.7 & 116.9 \\
\hline \multirow{3}{*}{$\begin{array}{l}480045 \\
480046\end{array}$} & $\begin{array}{l}1958-71 \\
1957-71\end{array}$ & & $\begin{array}{r}72.0 \\
110.0\end{array}$ & $\begin{array}{l}431.0 \\
521.0\end{array}$ & 61.3 & 50.0 & 151.5 & 136.1 \\
\hline & & Area 1 & & & 68.9 & 52.5 & 155.3 & 128.5 \\
\hline & & Area 2 & & & 66.9 & 48.9 & 137.1 & 125.3 \\
\hline \multirow{5}{*}{$\begin{array}{l}480071 \\
480073\end{array}$} & $1961-65$ & & 77.0 & 419.0 & 61.2 & 41.1 & 141.2 & 113.7 \\
\hline & $1960-70$ & & 360.0 & 1780.0 & & & & \\
\hline & & Area 1 & & & 63.9 & 49.6 & 180.8 & 122.3 \\
\hline & & Area 2 & & & 43.7 & 37.7 & 139.3 & 94.3 \\
\hline & & Area 3 & & & 67.7 & 47.1 & 186.9 & 122.5 \\
\hline \multirow[t]{3}{*}{$\begin{array}{l}490121 \\
500103\end{array}$} & $\begin{array}{l}1964-72 \\
1961-69\end{array}$ & & $\begin{array}{l}124.0 \\
105.0\end{array}$ & $\begin{array}{l}398.0 \\
243.0\end{array}$ & 40.6 & 44.4 & 45.6 & 139.0 \\
\hline & & Area 1 & & & 72.1 & 51.5 & 163.9 & 139.8 \\
\hline & & Area 2 & & & 83.3 & 55.5 & 179.6 & 133.5 \\
\hline \multirow{5}{*}{$\begin{array}{l}510087 \\
470017 \\
540009\end{array}$} & $1961-72$ & & 394.0 & 249.0 & 75.7 & 48.0 & 186.6 & 123.9 \\
\hline & $1961-72$ & & 277.0 & 594.0 & 51.2 & 41.7 & 139.4 & 113.8 \\
\hline & $1957-68$ & & 51.0 & 252.0 & & & & \\
\hline & & Area 1 & & & 72.9 & 40.9 & 157.7 & 101.1 \\
\hline & & Area 2 & & & 72.3 & 44.8 & 167.6 & 113.5 \\
\hline \multirow[t]{3}{*}{540010} & $1958-66$ & & 74.0 & 210.0 & & & & \\
\hline & & Area 1 & & & 63.8 & 44.2 & 164.9 & 117.3 \\
\hline & & Area 2 & & & 63.2 & 47.3 & 148.9 & 190.4 \\
\hline \multirow[t]{3}{*}{540049} & $1958-68$ & & 65.0 & 152.0 & & & & \\
\hline & & Area 1 & & & 79.4 & 47.1 & 143.3 & 111.3 \\
\hline & & Area 2 & & & 82.9 & 41.8 & 186.8 & 105.1 \\
\hline 540112 & $1962-64$ & & 70.0 & 206.0 & 64.0 & 43.2 & 139.6 & 99.5 \\
\hline 540115 & $1962-68$ & & 77.0 & 268.0 & 62.9 & 48.9 & 144.7 & 116.4 \\
\hline \multirow[t]{3}{*}{550038} & $1957-72$ & & 242.0 & 722.0 & & & & \\
\hline & & Area 1 & & & 69.5 & 45.7 & 164.9 & 127.4 \\
\hline & & Area 2 & & & 77.9 & 57.3 & 176.8 & 140.6 \\
\hline 550068 & $1960-72$ & & 703.0 & 878.0 & 50.9 & 40.1 & 131.0 & 99.6 \\
\hline 550129 & $1963-66$ & & 273.0 & 430.0 & 83.2 & 60.4 & 186.7 & 141.8 \\
\hline
\end{tabular}


TABLE 6

REGRESSION RESULTS FOR WHITE FEMALES $\left(R^{2}\right)$

\begin{tabular}{llll}
\hline Cancer site & CCE & CAE & CCE + CAE \\
\hline Esophagus & 0.000 & 0.013 & 0.012 \\
Stomach & 0.018 & $0.108^{*}$ & $0.109^{*}$ \\
Large intestine & $0.062^{*}$ & $0.070^{*}$ & $0.076^{*}$ \\
Rectum & 0.009 & $0.026^{*}$ & $0.027^{*}$ \\
Liver & 0.008 & 0.013 & 0.013 \\
Pancreas & 0.000 & 0.018 & 0.017 \\
Lung & 0.014 & $0.025^{*}$ & $0.027^{*}$ \\
Breast & $0.041^{*}$ & $0.077^{*}$ & $0.081^{*}$ \\
Kidney & 0.003 & 0.004 & 0.004 \\
Bladder & 0.003 & 0.011 & 0.011 \\
All sites & $0.059^{*}$ & $0.109^{*}$ & $0.116^{*}$ \\
\hline
\end{tabular}

drinking waters but not limited to them; the low-flow CAM (CAM-lf), which was introduced in the early 1960s for use for all types of surface water except drinking water in a distribution system. Almost all the stations shown in Table 5 initially employed the CAM-hf technique; however, sometime in the mid-1960s many stations converted to the CAM-lf procedure. Unfortunately, not all of the stations shown in Table 5 made this conversion. Therefore the mean for CCE and CAE were calculated, where possible, for the stations with both high flow and low flow measurements. The ratios of these means were calculated and that ratio (one for CCE and one for CAE) was applied to the stations with low flow values only. In this manner the data in Table 5 was all calculated to low-flow equivalents. In some cases the water source serves more than one county. Where this situation occurs the areas are labeled 1 and 2 , respectively.

The CAM method yields two extracts, carbon chloroform extract (CCE) and carbon alcohol extract (CAE). CCE provides a relative measure of pollution load not obtainable by other techniques. It reveals undue stress on a water from most industrial contaminants, particularly synthetic chemicals. CAE removes additional organic toxic material. There are some problems associated with measurement, for example CAE measurements tend to include inorganic salts. Nevertheless these measurements represent the only historical analysis of the organic content of drinking source water having been monitored for varying periods between 1957 and 1972 at 129 stations throughout the U.S.

One of the conclusions of the American Water Works Committee on Organic Contaminants in Water Supplies was "The historical CAE and CCE data returned from STORET constitute a wealth of information on the organic content of our national waters and should be the subject of extensive study and statistical evaluation" [21]. 
TABLE 7

REGRESSION RESULTS FOR WHITE MALE $\left(R^{2}\right)$

\begin{tabular}{llll}
\hline Cancer site & CCE & CAE & CCE + CAE \\
\hline Esophagus & $0.065^{*}$ & $0.110^{*}$ & $0.177^{*}$ \\
Stomach & $0.021^{*}$ & $0.094^{*}$ & $0.096^{*}$ \\
Large intestine & $0.073^{*}$ & $0.130^{*}$ & $0.138^{*}$ \\
Rectum & $0.061^{*}$ & $0.125^{*}$ & $0.131^{*}$ \\
Liver & 0.014 & $0.019^{*}$ & $0.021^{*}$ \\
Pancreas & 0.004 & 0.007 & 0.008 \\
Lung & $0.046^{*}$ & $0.059^{*}$ & $0.064^{*}$ \\
Breast & 0.001 & 0.000 & 0.000 \\
Kidney & 0.001 & 0.002 & 0.003 \\
Bladdex & $0.026^{*}$ & $0.052^{*}$ & $0.055^{*}$ \\
All sites & $0.086^{*}$ & $0.119^{*}$ & $0.128^{*}$ \\
\hline
\end{tabular}

TABLE 8

REGRESSION RESULTS FOR GI-URINARY TRACT SITES ${ }^{a}$

\begin{tabular}{llll}
\hline Class & CCE & CAE & CCE + CAE \\
\hline White Males & 0.080 & 0.174 & 0.183 \\
White Females & 0.055 & 0.141 & 0.147 \\
\hline
\end{tabular}

${ }^{\mathrm{a}}$ All $R^{2}$ are significant at the 0.01 level.

\section{REGRESSION ANALYSIS}

A regression analysis was performed between the sum of CAE and CCE, and cancer mortality. Cancer mortality data were taken from HEW's publication U.S. Cancer Mortality by County: 1950-1969 [22]. The age-adjusted 20-year average cancer mortality rates for those counties with STORET monitoring locations measuring $\mathrm{CAE}$ and $\mathrm{CCE}$ served as the dependent variable in the regression analysis.

The analysis itself is unique because it requires the merging of several data bases. Work being conducted at the Drinking Water Research Division of EPA in Cincinnati, Ohio developed the decision support system concept that was used in this analysis. Using remote or distributed terminals connected to the University of Michigan computer (Michigan Terminal System (MTS)), the investigators were able to rapidly analyze many possibilities. The results of this analysis are presented in this section. Tables 6 and 7 show the results of the regression analysis by site for white males and females. White males and females were used because the number of blacks in the data set for the STORET sites in Table 5 were extremely small.

Table 6 contains the value for $R^{2}$ for white females versus various cancer 

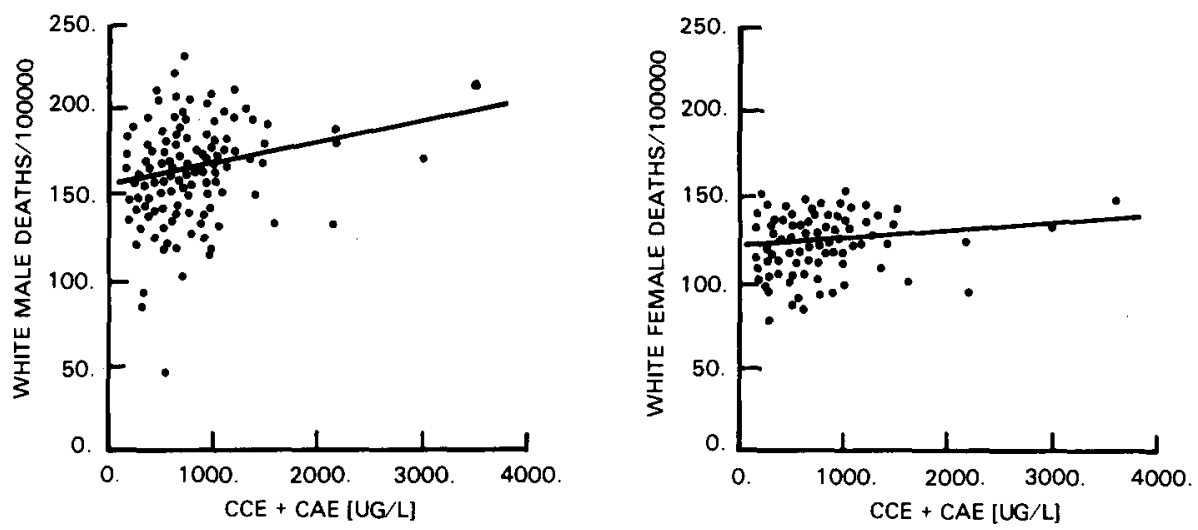

Fig. 2. Total cancer death rates versus CCE + CAE.
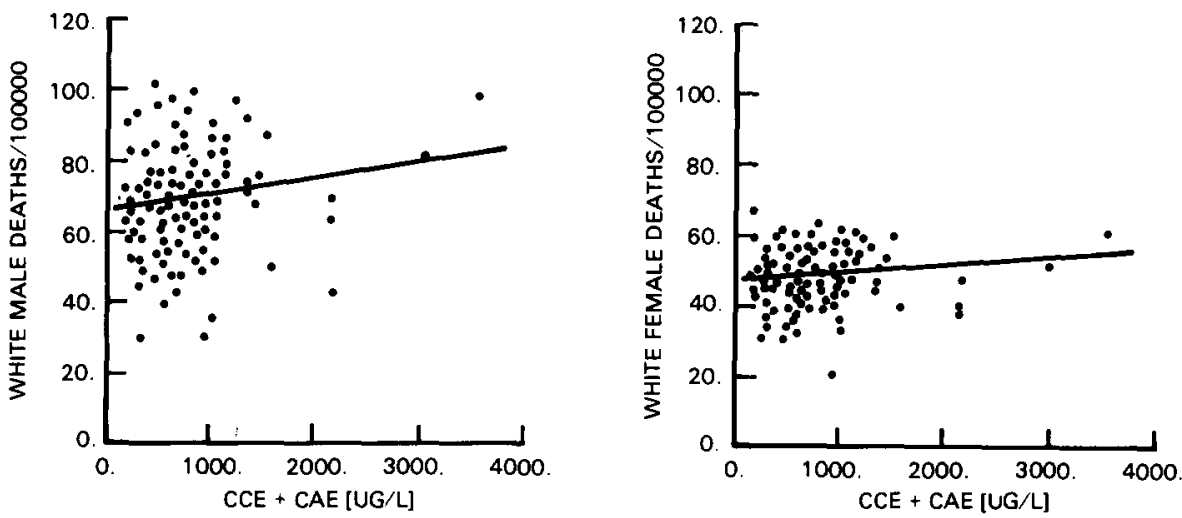

Fig. 3. GI-urinary tract cancer death rates versus $\mathrm{CCE}+\mathrm{CAE}$.

sites. The asterisk denotes those values which are significant at the 0.05 level or lower.

Table 7 contains the values for $R^{2}$ for white males for various sites versus CCE and CAE and CCE + CAE. The significant values at a level of 0.05 or less are denoted by an asterisk. As can be seen from Tables 6 and 7 the relationships for what might be termed GI-urinary tract cancer (esophagus, stomach, large intestine, rectum, kidney, pancreas, liver, bladder) are generally significant, although some of the $R^{2}$ are small.

Therefore the GI-urinary tract sites were aggregated and separate regressions were calculated. Cancer rates were regressed against CCE alone, CAE alone and CCE plus CAE (Table 8). These regressions are shown for white males and females using linear relationships. All of the $R^{2}$ in Table 8 are significant at the 0.01 level.

Figure 2 shows scattergrams of total cancer rates for white males and females versus CCE + CAE. Figure 3 shows scattergrams of cancer death rates for GI-Urinary tract versus CCE + CAE. 


\section{SUMMARY AND CONCLUSIONS}

The problem of understanding the health effects of organic chemical contaminants in drinking water is not new, but national concern has intensified in recent years. In 1979, EPA promulgated a regulation for the control of trihalomethanes in drinking water. Chloroform, a trihalomethane, is a suspected carcinogen and is formed by the interaction of chlorine and natural humic materials in water. Many other synthetic organics have also been identified at low levels in drinking water.

The total risk associated with exposure to multiple carcinogens may be greater than the sum of the risks posed by each chemical individually. due to synergistic interactions between carcinogens. The effects of exposure to carcinogens have a long latency; the time elapsing between exposure and clinical symptoms of the disease is often as much as $20-40$ years.

In an attempt to simulate the total exposure effect of organics in drinking water, CCE and CAE were correlated against cancer death rate. These parameters were taken from STORET data gathered in the 1957-1972 time period and against 20-year cancer death rates calculated from 1950 to 1969.

The results indicated highly significant relationships, particularly for GI-urinary tract cancers.

\section{REFERENCES}

1 F.M. Middleton and A.A. Rosen, Organic contaminants affecting the quality of water, Public Health Rep., 71(11) (1956) 1125-1133.

2 Public Health Service Drinking Water Standards, PHS Publication 956, U.S. Government Printing Office, Washington, 1962.

3 T.L. Bellar, T.T. Lichtenberg and R.C. Kroner, The occurrence of organohalides in chlorinated drinking water, J. Am. Water Works Assoc., 66 (1976) 703-706.

4 T.T. Rook, Formation of Haloforms during chlorination of natural waters, Water Treat. Exam., 23(2) (1974) 234-243.

5 W.E. Coleman et al., The occurrence of volatile organics in five drinking water supplies using gas chromatography/mass spectrometry, in L.H. Keith (Ed.), Identification and Analysis of Organic Pollutants in Water, Ann Arbor Science Publishers, Inc., Ann Arbor, Michigan, 1976, pp. 305-327.

6 R.D. Lingg et al., Quantitative analysis of volatile organic compounds by GC-MS, J. Am. Water Works Assoc., 69(11) (1977) 605-612.

7 National Cancer Institute, Report on the Carcinogenesis Bioassay of Chloroform, 1976.

8 T. Page, R.H. Harris and S.S. Epstein, Drinking water and cancer mortality in Louisiana, Science, 193 (1976) 55.

9 EPA Region VI, Analytical Report - New Orleans Area Water Supply Study, EPA906/9-75-003, Surveillance and Analysis Division, Dallas, TX, 1975.

10 National Interim Primary Drinking Water Regulations Control of Trihalomethanes in Drinking Water: Final Rule, Federal Register 1979, 44(231) 68624-68705.

11 W.C. Hueper and W.D. Conway, Chemical Carcinogenesis and Cancer, Charles C. Thomas, Springfield, 1964.

12 J.M. Symons et al., National organics reconnaissance survey for halogenated organics, J. Am. Water Works Assoc., 67(1975) 634. 
13 T. Page, R.H. Harris and J. Bruser, Removal of Carcinogens from Drinking Water: A Cost-Benefit Analysis, Social Science Working Paper 230, Division of Humanities and Social Sciences, California Inst. of Technology, Pasadena, California, January, 1979.

14 W.S. Carlson and J.B. Andelman, Environmental Influences on Cancer Morbidity in the Pittsburgh Region, USEPA Health Effects Research Laboratory, Cincinnati, Ohio, EPA/CA-6-00-3379-J, April, 1977.

15 National Organics Monitoring Survey (NOMS), EPA Office of Water Supply, 1977.

16 American Cancer Society, 1981 Cancer Facts and Figures, p.3.

17 T.D. McKinney, R.R. Maureo, J.R. Hass and R.D. Thomas, Possible factors in the drinking water of laboratory animals causing reproductive failures, in L.H. Keith (Ed), Identification and Analysis of Organic Pollutants in Water, Ann Arbor Science Publishers, Inc., Ann Arbor, Michigan, 1976.

18 National Academy of Science (NAS), Summary Report: Drinking Water and Health, Safe Drinking Water Committee, NRC, NAS, Washington, D C, 1977.

19 T.T. Lichtenberg, Determination of pesticides in water and wastewater, in Proceedings, AWWA Water Quality Technology Conference, Paper XXI, Cincinnati, Ohio, Dec 2 and 3, 1973.

20 R.C. Dressman and E.F. McFarran, The detection and measurement of bis(2)-chloroethers and dieldrin by gas chromatography, presented at AWWA Water Quality Conference, Dallas, TX, Dec. 2 and 3, 1974.

21 Committee Report: Organic Contaminants in Water Supplies, J. Am. Water Works Assoc. 67(8) (1975) 418-424.

22 T.J. Mason, and F.W. McKay, U.S. Cancer Mortality by County: 1950-1969. DHEW Publication No. (NIH) 74-665. 